\title{
An experimental analysis of the Trombe wall temperature fluctuations for high range climate conditions: Influence of ventilation openings and shading devices
}

\author{
Ana Briga Sáa,b,*, José Boaventura-Cunha ${ }^{\mathrm{b}, \mathrm{c}}$, João-Carlos Lanzinha ${ }^{\mathrm{a}, \mathrm{d}}$, Anabela Paiva ${ }^{\mathrm{a}, \mathrm{b}}$ \\ ${ }^{a}$ C - MADE - Centre of Materials and Building Technologies, University of Beira Interior, 6201-001 Covilhã, Portugal \\ ${ }^{\mathrm{b}}$ ECT - School of Science and Technology, University of Trás-os-Montes e Alto Douro UTAD, Quinta de Prados, $5000-801$ Vila Real, Portugal \\ ' INESC TEC - INESC Technology and Science (formerly INESC Porto) and ECT - School of Science and Technology, University of Trás-os-Montes e Alto Douro, \\ Portugal \\ d University of Beira Interior, 6201-001 Covilhã, Portugal
}

\section{A R T I C L E I N F O}

\section{Article history:}

Received 9 February 2016

Received in revised form

23 December 2016

Accepted 30 December 2016

Available online 31 December 2016

\section{Keywords:}

Trombe wall

Thermal performance

Temperature fluctuation

Ventilation openings

Shading devices

Experimental work

\begin{abstract}
A B S T R A C T
Despite the studies already developed about Trombe walls, more research work is needed to contribute to the knowledge about their behaviour and optimize it according to the specific characteristics of each climatic region. The ventilation openings and the shading device operation decisively influence the temperatures fluctuation along the system and that impact should be discussed.

In this context, a test cell with a classical Trombe wall was submitted to real climatic conditions in a Portuguese city. The effect of ventilation openings and shading devices in the temperatures fluctuation was analysed.

The temperatures in the air layer and along the massive wall presented a similar oscillation pattern and exceeded $60{ }^{\circ} \mathrm{C}$ without ventilation and shading devices. For this configuration, temperature values at the top of the air layer were always higher than those obtained at the base and a differential of $19{ }^{\circ} \mathrm{C}$ was achieved.

The temperature fluctuation across the massive wall was not proportional to its thickness due to its heat storage capacity.

When the ventilation system was closed and the shading device was not activated, the temperature inside the test cell exceeded the outside temperature value in $9{ }^{\circ} \mathrm{C}$, showing the system ability to store and release heat.
\end{abstract}

(c) 2016 Elsevier B.V. All rights reserved.

\section{Introduction}

Passive solar systems can be used to improve buildings energy efficiency [1-5]. Trombe wall is a passive solar system of indirect gain that enhances the materials ability to store and release heat, based on the heat transfer phenomena. The classical Trombe wall is composed, from the interior to the exterior, by a massive wall made of materials with high heat storage capacity, an air layer and a glazing outside. The massive wall external surface should be dark in colour to increase the solar radiation absorption [6,7]. Ventilation openings are provided in the massive wall to improve heat transfer by air convection [8]. In Fig. 1(b) it is presented a schematic design

* Corresponding author at: ECT - School of Science and Technology, University of Trás-os-Montes e Alto Douro UTAD, Quinta de Prados, 5000-801 Vila Real, Portugal. E-mail address: anas@utad.pt (A. Briga Sá). of a classical Trombe wall. If the ventilation openings are operating, the system will be defined in this research work as Ventilated Trombe Wall (VTW). When they are closed, it will be named as NonVentilated Trombe Wall (NVTW), Fig. 1(a). Despite Trombe wall is commonly used as a passive heating solution, it can also be used as a cooling one when there are ventilation openings simultaneously in the massive wall and in the glazing [9-12], Fig. 1(c), defined as Double Ventilated Trombe Wall (DVTW).

Shading devices should also be considered in the system in order to reduce the overheating periods during summer days and the heat losses during winter nights.

Over the years, various studies have been carried out to analyse the Trombe wall performance. New concepts depending on the massive wall materials [13-19], the glazing type [10,20-22], the ventilation openings type [23-27] and the use of thermal insulation emerged [28,29]. 

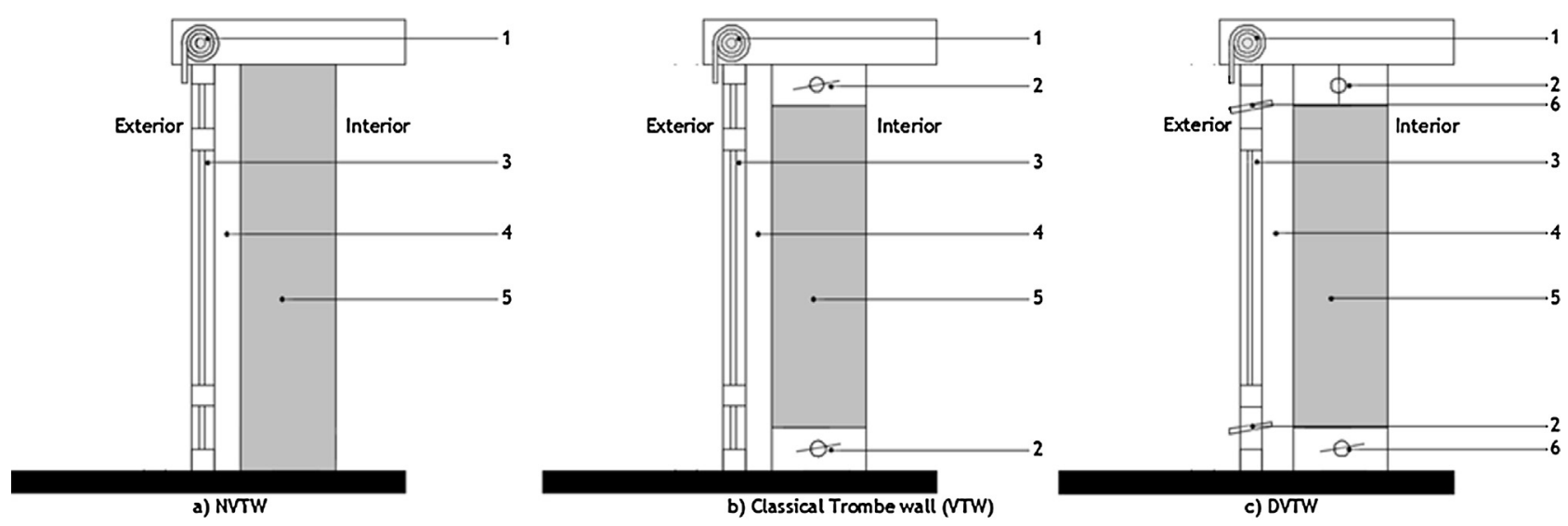

1-Shading device; 2-Ventilation openings in the massive wall; 3- Glazing; 4-Air layer; 5-Massive wall; 6-Ventilation openings in the glazing

Fig. 1. Different types of Trombe walls: a) Non-ventilated (NVTW); b) Classic or ventilated (VTW); c) Double ventilated (DVTW).

The ventilation system has a fundamental role in the Trombe wall thermal behaviour taking into account the additional heat flux that will occur through the ventilation openings. Studies conducted on this area are essentially about Trombe walls with ventilation openings in the massive wall. As an example of the studies already developed addressing this issue, an optimization research on the opening and closing model of the Trombe wall was conducted using experimental research and numerical calculation [30]. The optimum time to open and close the air vents was analysed. It was concluded that the system should be opened $2-3 \mathrm{~h}$ after sunrise and closed $1 \mathrm{~h}$ before sunset.

In what concerns to the materials, solid brick and concrete are the ones that are used more often in the massive walls $[6,19]$, although there are studies that combine them with other materials, such as phase change materials [31,32], photovoltaic cells and thermal insulation $[11,15,33]$.

As referred above, the shading device has an important role to avoid the overheating during the summer and the heat losses during the night periods of winter. The influence of the shading devices in the system behaviour was studied for the case of shading devices introduced in the air layer [34]. It is also necessary to optimize the use of external shading devices given that it will be a better solution to minimize the risk of overheating during the summer in climates with high solar radiation intensity. In a recent study considering this issue, the Trombe wall thermal performance was analysed for summer under Mediterranean climate. The effect of screening devices, ventilation and occupancy was analysed. It was concluded that these factors affect significantly the thermal parameters of the Trombe wall in summer, namely the surface temperatures. They concluded that roller shutters have a relevant influence in the reduction of the surface temperatures of $-1.4{ }^{\circ} \mathrm{C}$ and that velocity in the cavity is influenced by the temperatures in the air gap [35].

The international standard document ISO 13790:2008(E) [36], relative to the energy performance of buildings in what concerns to the calculation of energy use for space heating and cooling, presents a set of equations to obtain the heat transfer and solar heat gains of special elements that can be the base to define a calculation methodology of the Trombe wall thermal performance. However, its application requires adaptation to different climate realities. In previous work developed by the research team related with the definition of a calculation methodology to estimate the Trombe wall thermal performance based on this standard document, it was observed that the temperature values in different points of the wall are needed [37]. This reveals that experimental study about Trombe wall thermal performance is required in order to anal- yse the impact of the outdoor climatic conditions, ventilation and shading devices operation in the temperature fluctuation in different points of the system. Furthermore, according to the literature review, more studies should be developed in order to identify the relation between those temperature values. Temperatures variation in different points of the air layer and massive wall should also be analysed for different seasons, including the transition between them characterized by high range climate conditions.

So, given the specificity of the Trombe wall, experimental analysis using test cells under real conditions $[23,38]$ are very useful to the analysis and further adaptation of this passive system to different climate conditions.

In the Portuguese reality, and according to the literature review, this wall has not a significant application [19,23,24,39]. Most of the stakeholders involved in the construction sector are unaware of this solution or do not have enough information about its thermal performance. The lack of information about its construction is also a problem, namely in what concerns to the constructive details $[23,39]$ and costs. Gonçalves et al. [40] referred some Portuguese buildings where the Trombe wall was built. The majority of them does not have any openings and has single glazing. In terms of summer protection, some have movable or fixed shades but in other cases any shading device was provided. This lack of knowledge, which is common in different countries, is an obstacle to increase the use of such solutions to improve buildings energy efficiency, whose study should start in the design stage [19,24]. This situation shows that there is still a lot of work to be done in order to encourage the use of Trombe walls in buildings construction and to optimize its performance according to the specific characteristics of each climatic region.

In order to contribute to this knowledge, the experimental study of a classical Trombe wall thermal performance, using a test cell submitted to real climatic conditions in a city of Portugal, will be presented. This work is included in a research line that includes simulation and experimental analysis of the Trombe wall thermal performance and reveals the importance of measurements for real weather conditions $[19,23,24]$. The aim of the work here presented is to reveal the influence of the ventilation openings and shading devices operation in the system performance under different values of solar radiation intensity and exterior temperatures. The analysis of its performance will be carried out taking into account the temperature fluctuation values that occur in different points of the Trombe wall, the heat flux through the system and the temperature values obtained inside the test cell.

In order to perform this study, different periods of VTW and NVTW, using shading devices or not, were considered for a mea- 


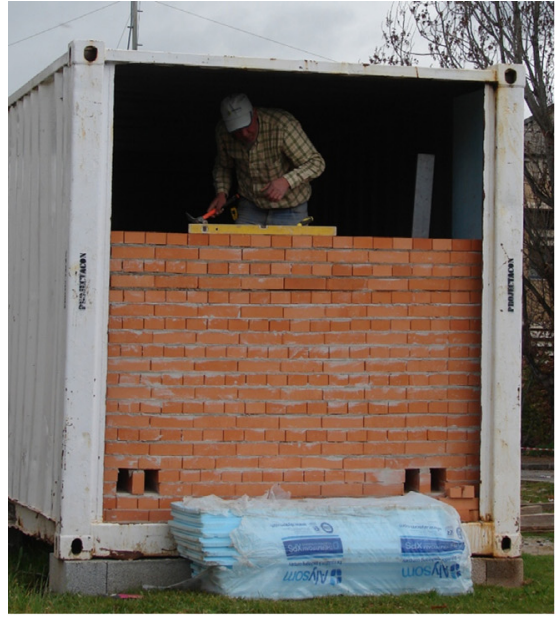

a)

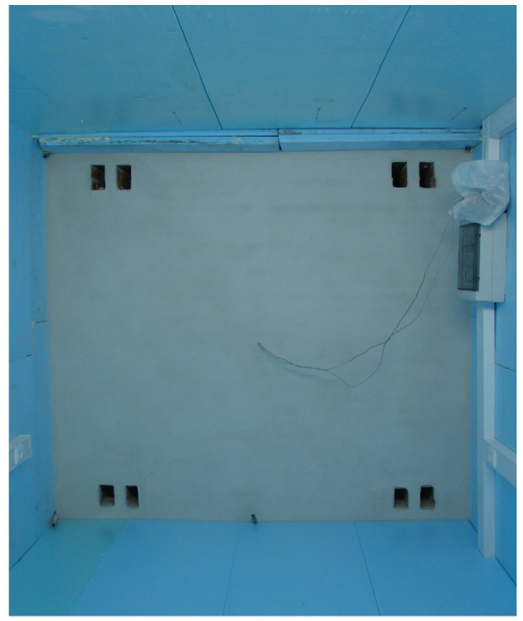

b)

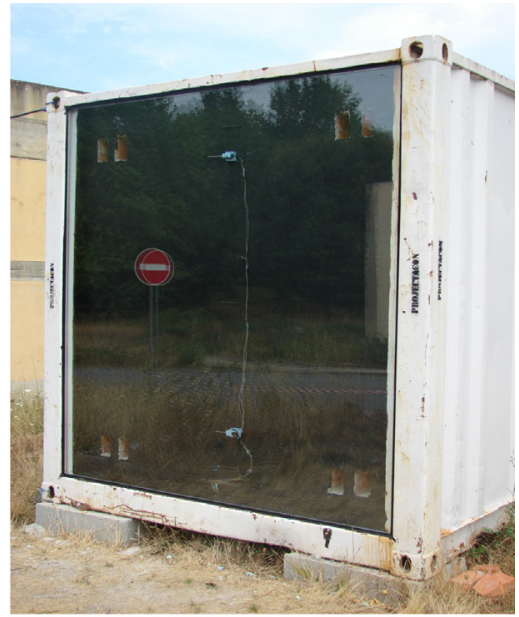

c)

Fig. 2. Trombe wall construction: a) massive wall construction; b) envelope insulated with XPS; c) Trombe wall system.

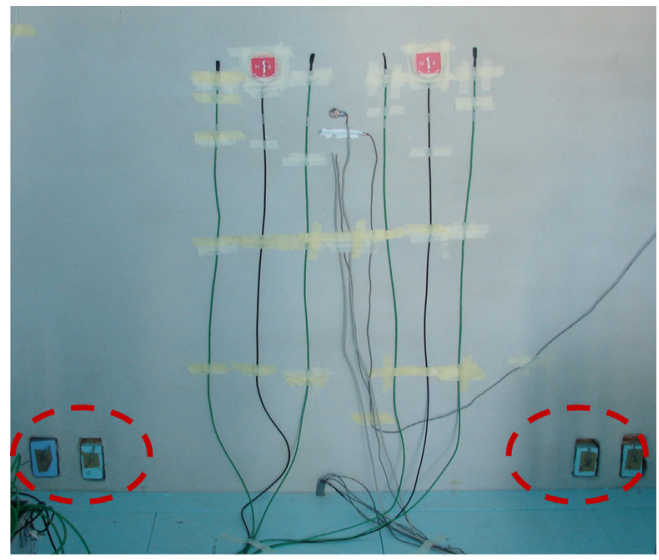

a)

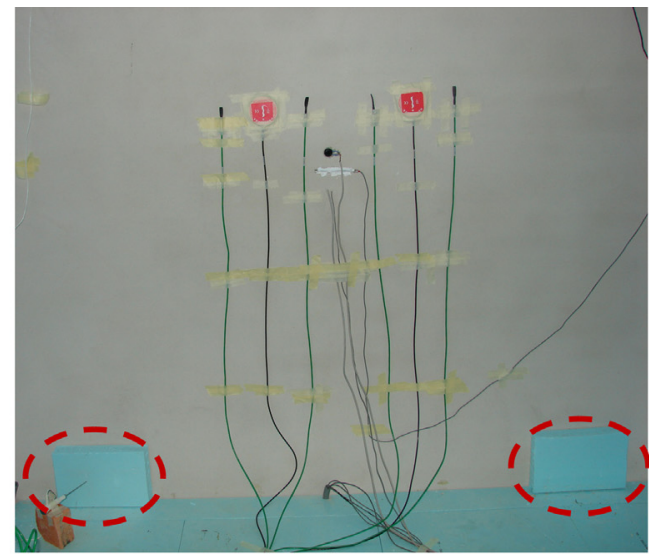

b)

Fig. 3. Ventilation system obturators: a) obturators Type 1 ; b) obturators Type 2.

surement period that included part of the heating and cooling seasons. It is important to refer that the periods of the different configurations operation were defined in an aleatory way in order to stimulate the system and analyse the impact of those changes on its performance. So, the system behaviour optimization was not a goal to achieve at this time of the research work. Furthermore, this study will give a contribution to the application of ISO 13790:2008(E) [36], whose equations require the knowledge of the temperatures values in different points of the wall, as referred previously. Moreover, the temperature values in the different layers will be compared and a relation between them will be established whenever possible.

Taking into account that this experimental work has been developed in a region with high temperatures range during the day and during the year, the obtained results can also be a contribution to the knowledge of the system behaviour in other regions with similar climatic conditions, namely in Southern European countries.

\section{Methodology}

\subsection{Experimental device}

The experimental work developed allowed to analyse the Trombe wall thermal performance under the real weather conditions of the city of Vila Real that lies $458 \mathrm{~m}$ above the sea level and
Table 1

Climatic data for the city of Vila Real [41].

\begin{tabular}{lll}
\hline Parameters & Units & Value \\
\hline Heating season length & months & 7 \\
Cooling season length & months & 5 \\
Annual temperature range & ${ }^{\circ}$ C & 15 \\
Degrees-days & ${ }^{\circ}$ C.days & 2660 \\
Solar irradiance in heating season (south) & $\mathrm{kWh} / \mathrm{m}^{2}$.month & 90 \\
Solar irradiance in cooling season (south) & $\mathrm{kWh} / \mathrm{m}^{2}$ & 420 \\
Outside air temperature average in cooling season & ${ }^{\circ} \mathrm{C}$ & 19 \\
\hline
\end{tabular}

has the coordinates $41^{\circ} 17^{\prime} 11.86^{\prime \prime} \mathrm{N}$ and $7^{\circ} 44^{\prime} 29.01^{\prime \prime} \mathrm{W}$. The climate in this city is characterized by high diurnal and annual temperature range and also by high solar radiation intensity values. Climatic data included in the Portuguese thermal regulation for this city is presented in Table 1 [41].

A test cell, including a classical Trombe wall was designed, constructed, instrumented and monitored. The Trombe wall southern orientation and the minimization of the external obstacles effects were ensured.

The instrumentation and monitoring of the Trombe wall allowed to measure different parameters related to its thermal behaviour under dynamic conditions. Temperature values in different points of the system and the heat flux through the wall were acquired. Temperature, solar radiation and relative humidity were measured 
outside the test cell. The temperature and the relative humidity were also monitored inside the test cell. These parameters will be described in more detail in section 2.1.3.The measurement period occurred between the 11th August and the 4th November of 2011 and corresponded to the transition between the heating and the cooling seasons in Portugal. Data acquisition was made at time intervals of five minutes.

The aspects taken into account during the different stages of the experimental work related to the test cell design, construction and monitoring will be presented in the following sections. The Trombe wall characteristics, namely in what concerns to the materials, thicknesses of the different layers and air openings were defined considering the results obtained in previous work developed by the research team and others showed by other authors, as will be referred in the following sections.

The acquired values for the different parameters, namely outdoor and indoor climatic conditions and temperature fluctuation through the Trombe wall will also be analysed. The influence of the ventilation openings and shading devices in the Trombe wall behaviour will be discussed.

\subsubsection{Test cell configuration}

The test cell was built based on a metallic container usually used in the building construction. The container south façade was removed to allow the construction of the Trombe wall, as it can be seen in Fig. 2(a). Concrete blocks were used to avoid the thermal bridges resultant from the contact between the container floor and the soil. The heat gains and losses through the container were reduced applying thermal insulation in the interior of the external envelope. Extruded polystyrene (XPS) with $12 \mathrm{~cm}$ of thickness was placed on the roof and floor and $8 \mathrm{~cm}$ of it on the other three walls, as shown in Fig. 2(b).

These thickness values were defined in order to guarantee the reference values for the city of Vila Real defined in the Portuguese thermal regulation, which are $0.5 \mathrm{~W} / \mathrm{m}^{2}{ }^{\circ} \mathrm{C}$ for walls and $0.4 \mathrm{~W} / \mathrm{m}^{2}{ }^{\circ} \mathrm{C}$ for floors and roofs [41]. After the container insulation, it was obtained the heat transfer coefficients values of $0.43 \mathrm{~W} / \mathrm{m}^{2}{ }^{\circ} \mathrm{C}$ for walls and $0.30 \mathrm{~W} / \mathrm{m}^{2}{ }^{\circ} \mathrm{C}$ for the floor and the roof. The final dimensions of the test cell are $6 \mathrm{~m}$ (length) $\times 2.4 \mathrm{~m}$ (width) $2.3 \mathrm{~m}$ (height), resulting in approximately $14 \mathrm{~m}^{2}$ of useful area and $33 \mathrm{~m}^{3}$ of volume. The design characteristics of this experimental device are similar to those required in PASSYS test cells used for the analysis of building components thermal behaviour [42].

\subsubsection{Trombe wall system}

The experimental study was carried out for a classical Trombe wall. The ceramic solid brick was used as the massive wall storage material with $34 \mathrm{~cm}$ of thickness. The Trombe wall constructive details were defined based on previous research developed by the research team. This research work showed that, for the climate zone of Vila Real, a Trombe wall with a massive wall made of ceramic solid brick has a better performance than if it is made of granite or concrete $[19,23]$.

The Trombe wall has approximately $6 \mathrm{~m}^{2}$. This value is consistent with the research work developed by other authors that define the relation between the Trombe wall area and the served room area, taking into account the average temperature of the heating season for regions with high temperatures ranges [19,43]. In order to increase the absorption capacity of the massive wall [6,7], its external surface was painted black, leading to an absorption coefficient value of 0.8 . The ventilation system of the massive wall is composed by four openings at the bottom and four openings at the top, ensuring the higher distance between the upper and lower openings in order to increase the heat flow by air convection. According to other studies, a higher number of openings with smaller dimensions is more appropriate than one larger opening

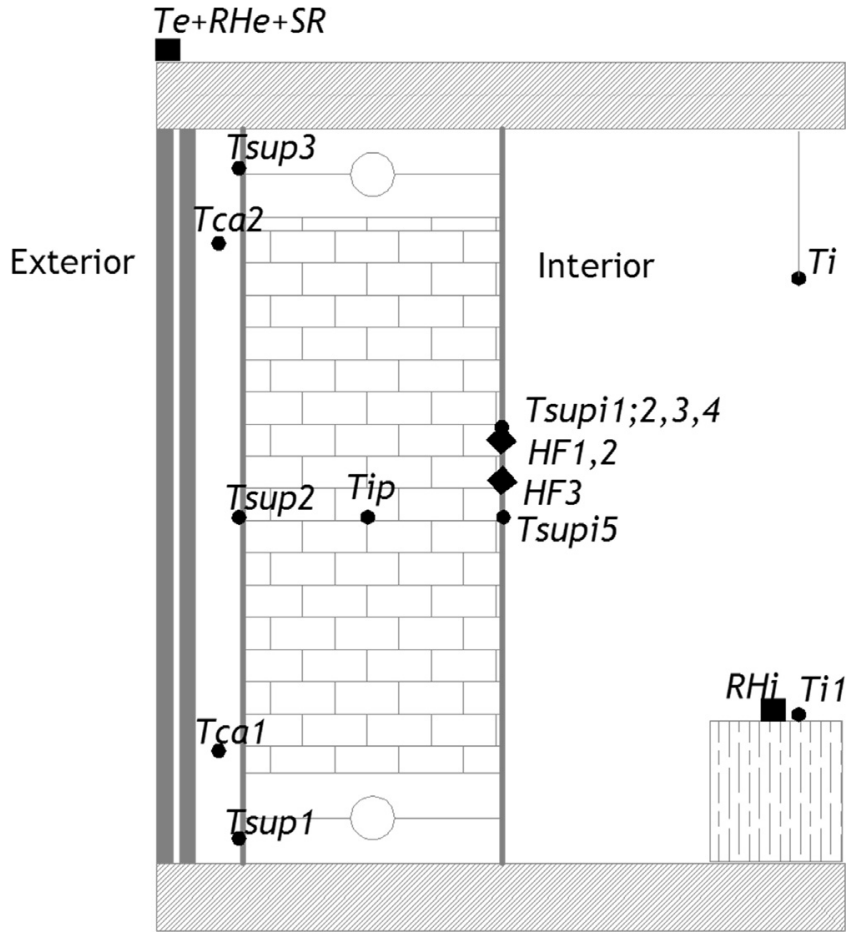

Fig. 4. Sensors Location.

at the top and one at the bottom due to the increasing of heat flux by convection through the openings [31]. The ventilation openings area is approximately $2 \%$ of the Trombe wall area, which is a recommended value according to the literature review $[3,44]$. In order to analyse the ventilation system effect on the Trombe wall thermal behaviour, two types of obturators made of XPS boards were used in the experimental work to cover the openings as shown in Fig. 3 (obturators Type I (Fig. 3a)) and obturators Type 2 (Fig. 3b)).

The air layer thickness between the massive wall and the glazed surface is approximately $6 \mathrm{~cm}$, fitting on the values reported by other authors $[3,45]$. A double colourless glazing with a thickness of $5 \mathrm{~mm}$ in the glass layers and $12 \mathrm{~mm}$ in the air gap was placed outside in order to guarantee the heat storage in the air layer, to increase the heat gains and to reduce heat losses from inside to outside when the heat flux inversion occurs in the system. Before placing the glazing outside, it was necessary to insulate the air layer sides to reduce the thermal bridges and increase the heat storage obtained by the greenhouse effect. In Fig. 2(c), the studied Trombe wall is presented. In order to analyse the shading devices influence on the Trombe wall performance, XPS panels were placed outside, simulating exterior shading devices.

\subsubsection{Test cell instrumentation and monitoring}

The instrumentation and monitoring of the test cell submitted to real weather conditions allowed to obtain a continuous acquisition of the different parameters related to the Trombe wall thermal performance [24].

The values of the different variables were obtained for periods of $5 \mathrm{~min}$ resulting from the average values collected every $30 \mathrm{~s}$. In Table 2, the different test periods of the experimental work are listed. The changes made in the ventilation openings and in the exterior shading devices operation are also represented in the graphics to better understand the influence of the different Trombe wall configurations in the temperature values and in the heat flux. Periods of NVTW with obturators Type 1 and Type 2 and periods of VTW were considered in order to analyse the impact of open or 
Table 2

Experimental period characterization.

\begin{tabular}{|c|c|c|c|c|c|c|c|c|}
\hline \multicolumn{3}{|l|}{ Test Period } & \multicolumn{6}{|c|}{ Test period characteristics } \\
\hline \multirow[t]{3}{*}{ Configuration } & \multirow[t]{3}{*}{ Start date } & \multirow[t]{3}{*}{ End date } & \multicolumn{4}{|c|}{ Ventilation openings } & \multicolumn{2}{|c|}{ Exterior shading devices } \\
\hline & & & \multicolumn{2}{|c|}{ Obturators Type 1} & \multicolumn{2}{|c|}{ Obturators Type 2} & \multirow[t]{2}{*}{ Yes } & \multirow[t]{2}{*}{ No } \\
\hline & & & Yes & No & Yes & No & & \\
\hline VTW/NSD & $11 / 08 / 1116: 20$ & 15/09/11 9:00 & & $\mathrm{X}$ & & $\mathrm{X}$ & & $\mathrm{X}$ \\
\hline NVTW1/NSD & 15/09/11 9:15 & 19/09/11 14:00 & $\mathrm{X}$ & & & $\mathrm{X}$ & & $\mathrm{X}$ \\
\hline NVTW2/NSD & $19 / 09 / 1114: 35$ & $04 / 10 / 1116: 25$ & & $\mathrm{X}$ & $\mathrm{X}$ & & & $\mathrm{X}$ \\
\hline NVTW2/SD & 04/10/11 16:30 & 05/10/11 14:35 & & $\mathrm{X}$ & $\mathrm{X}$ & & $\mathrm{X}$ & \\
\hline VTW/NSD & 05/10/11 14:40 & 06/10/11 08:30 & & $\mathrm{X}$ & & $\mathrm{X}$ & & $\mathrm{X}$ \\
\hline NVTW2/SD & 06/10/11 08:50 & 07/10/11 09:00 & & $\mathrm{X}$ & $\mathrm{X}$ & & $\mathrm{X}$ & \\
\hline NVTW2/NSD & 07/10/11 09:05 & 07/10/11 13:20 & & $\mathrm{X}$ & $\mathrm{X}$ & & & $\mathrm{X}$ \\
\hline NVTW2/SD & $07 / 10 / 1113: 25$ & $10 / 10 / 1116: 40$ & & $\mathrm{X}$ & $\mathrm{X}$ & & $\mathrm{X}$ & \\
\hline NVTW2/NSD & $10 / 10 / 1116: 45$ & $11 / 10 / 1114: 10$ & & $\mathrm{X}$ & $\mathrm{X}$ & & & $\mathrm{X}$ \\
\hline NVTW2/SD & $11 / 10 / 1114: 15$ & $14 / 10 / 1112: 25$ & & $\mathrm{X}$ & $\mathrm{X}$ & & $\mathrm{X}$ & \\
\hline NVTW2/NSD & $14 / 10 / 1112: 30$ & $15 / 10 / 1108: 55$ & & $\mathrm{X}$ & $\mathrm{X}$ & & & $\mathrm{X}$ \\
\hline NVTW2/SD & 15/10/11 09:00 & $17 / 10 / 1112: 00$ & & $\mathrm{X}$ & $\mathrm{X}$ & & $\mathrm{X}$ & \\
\hline NVTW2/NSD & $17 / 10 / 11$ 12:05 & $17 / 10 / 11$ 15:55 & & $\mathrm{X}$ & $\mathrm{X}$ & & & $\mathrm{X}$ \\
\hline NVTW2/SD & $17 / 10 / 1116: 00$ & 18/10/11 11:05 & & $\mathrm{X}$ & $\mathrm{X}$ & & $\mathrm{X}$ & \\
\hline NVTW2/NSD & $18 / 10 / 1111: 10$ & 02/11/11 16:55 & & $\mathrm{X}$ & $\mathrm{X}$ & & & $\mathrm{X}$ \\
\hline NVTW2/SD & $02 / 11 / 11$ 17:00 & $04 / 11 / 11$ 12:15 & & $\mathrm{X}$ & $\mathrm{X}$ & & $\mathrm{X}$ & \\
\hline
\end{tabular}

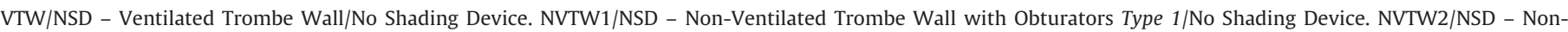
Ventilated Trombe Wall with Obturators Type 2/No Shading Device. NVTW2/SD - Non-Ventilated Trombe Wall with Obturators Type 2/Shading Device.

close the ventilation system in the temperatures stratification. The effect of shading devices was also considered in aleatory periods.

Several devices were used to measure the outdoor and indoor environmental conditions, as well as the different temperatures that characterize the system thermal performance. Air temperature, relative humidity and solar radiation were measured outside the test cell. The air temperature and relative humidity values were also acquired inside the test cell using a thermo-hygrometer system with relative humidity and air temperature probes. The values of the exterior and interior relative humidity are not considered in this analysis.

The Trombe wall was instrumented in order to obtain the temperatures in different points of the different layers that compose the system. The heat flux through the wall was also measured. The temperatures acquisition was made using temperature sensors placed in the air layer and in the massive wall. In Fig. 4, a schematic presentation of the different sensors location is given. In Table 3 , a detailed description of the sensors designation, parameter measured, units, specific location, sensor type and precision is presented.

Two temperature sensors were placed in the air layer, one at the bottom, Tca1, and the other at the top, Tca2. Three temperature sensors were placed on the massive wall external surface, one at the bottom, Tsup1, one at the middle, Tsup2, and one at the top, Tsup3, as presented in Fig. 5(a).

During the construction of the massive wall, a temperature sensor, Tip, was placed at half of the thickness and at half of the wall height.

Two heat fluxmeters, HF1 and HF2, a heat flux sensor, HF3, and five temperature sensors,Tsupi1, Tsupi2, Tsupi3, Tsupi4 and Tsupi5, were placed on the internal surface of the massive wall, as shown in Fig. 5(b).

\section{Results and discussion}

In this section, the results obtained during the experimental work will be analysed and discussed with detail. Firstly, the analysis of the values obtained regarding the outdoor climate will be done. Then, the impact of these values in the temperature variation in the different layers of the Trombe wall will be analysed and linked. The influence of the air openings and the shading devices operation in those values will be discussed. Finally, the analysis of the tem- perature obtained inside the test cell will also be made in order to identify for what conditions the comfort values can be achieved.

As a complement of this analysis, diagram of temperatures across the wall will be presented.

\subsection{Outdoor climate}

The outdoor climate was analysed considering the solar radiation intensity $(S R)$ and the exterior temperature $(T e)$ values. The $S R$ values were quite high during a large part of the test period. This was expected given that the analysed period corresponds to the transition between the cooling and the heating seasons. In Fig. 6, the obtained values for these parameters are presented. The maximum value of $S R$ reached $0.9 \mathrm{KW} / \mathrm{m}^{2}$. The beginning of October was characterized by a set of unusual high temperatures for this time of the year, considered the highest in the last 50 years, and also by high values of solar radiation. In the end of October, $S R$ values started to decrease. A general visualization of Fig. 6 shows higher values during the periods corresponding to the cooling season and a reduction in the periods that corresponds to the transition between the cooling and the heating season. A detailed analysis of the beginning and the end of the measurement period, presented in Fig. 7, shows that, during the period between 5 th and 13th August, $S R$ values were much higher than the ones obtained in the end of the test period, corresponding to the period between 27 th October and 4th November of 2011. In the first case, $S R$ values followed a more uniform oscillation curve, reaching maximum values around $0.80 \mathrm{~kW} / \mathrm{m}^{2}$, while in the second case, those values decreased significantly and presented higher oscillations due to the cloud cover variation, reaching a maximum value around $0.50 \mathrm{~kW} / \mathrm{m}^{2}$. In the first period, $S R$ values contributed to increase the solar heat gains through the Trombe wall, while in the second period, $S R$ values were characterized by high oscillations during the day, reducing the potential use of solar energy by the system. These $S R$ oscillations had an important impact in the Trombe wall thermal performance, as it will be observed in the temperature fluctuation for the different layers of the system. In what concerns to the outdoor air temperature, Te, Fig. 6, the maximum values achieved varied between $30^{\circ} \mathrm{C}$ and $40^{\circ} \mathrm{C}$, in a high number of days, reducing significantly, as expected, in the last twenty days of the analysed period due to the beginning of the heating season. This temperature assumed a maximum value of $39.73^{\circ} \mathrm{C}$ on 12 th August and a mini- 
Table 3

\begin{tabular}{|c|c|c|c|c|c|}
\hline Sensor designation & Parameter & Units & Location & Sensor Type & Precision \\
\hline $\mathrm{Ti}$ & indoor air temperature & ${ }^{\circ} \mathrm{C}$ & in the middle of the test cell at $200 \mathrm{~cm}$ from the floor & TM1 Delta-T & $\pm 0.1^{\circ} \mathrm{C}$ \\
\hline Ti1 & indoor air temperature & ${ }^{\circ} \mathrm{C}$ & in the middle of the test cell at $60 \mathrm{~cm}$ from the floor & Hanna Instruments & $\pm 0.2^{\circ} \mathrm{C}$ \\
\hline $\mathrm{Te}$ & outdoor air temperature & ${ }^{\circ} \mathrm{C}$ & roof & RHA1 Vaisala & $\pm 0.1^{\circ} \mathrm{C}$ \\
\hline RHe & outdoor relative humidity & $\%$ & roof & Hanna Instruments & $\pm 2 \%$ \\
\hline RHi & indoor relative humidity & $\%$ & in the middle of the test cell at $60 \mathrm{~cm}$ from the floor & BF3 Delta-T & $\pm 2 \%$ \\
\hline $\mathrm{SR}$ & total solar radiation & $\mathrm{W} / \mathrm{m}^{2}$ & roof & TM1 Delta-T & $\pm 5 \mathrm{~W} / \mathrm{m}^{2}$ \\
\hline Tca1 & air layer temperature & ${ }^{\circ} \mathrm{C}$ & in the middle of the air layer at $30 \mathrm{~cm}$ from the bottom & TM1 Delta-T & $\pm 0.1^{\circ} \mathrm{C}$ \\
\hline Tca2 & air layer temperature & ${ }^{\circ} \mathrm{C}$ & in the middle of the air layer at $30 \mathrm{~cm}$ from the top & TM1 Delta-T & $\pm 0.1^{\circ} \mathrm{C}$ \\
\hline Tsup1 & massive wall external surface temperature & ${ }^{\circ} \mathrm{C}$ & in the massive wall external surface at $10 \mathrm{~cm}$ from the bottom & TM1 Delta-T & $\pm 0.1^{\circ} \mathrm{C}$ \\
\hline Tsup2 & massive wall external surface temperature & ${ }^{\circ} \mathrm{C}$ & at half-height of the massive wall external surface & TM1 Delta-T & $\pm 0.1^{\circ} \mathrm{C}$ \\
\hline Tsup3 & massive wall external surface temperature & ${ }^{\circ} \mathrm{C}$ & in the massive wall external surface at $10 \mathrm{~cm}$ from the top & TM1 Delta-T & $\pm 0.1^{\circ} \mathrm{C}$ \\
\hline Tip & massive wall internal temperature & ${ }^{\circ} \mathrm{C}$ & at half of the thickness and half of the height of the massive wall & TM1 Delta-T & $\pm 0.1^{\circ} \mathrm{C}$ \\
\hline Tsupi1 & massive wall internal surface temperature & ${ }^{\circ} \mathrm{C}$ & in the massive wall internal surface at $120 \mathrm{~cm}$ from the floor & Hukseflux & $\pm 0.1^{\circ} \mathrm{C}$ \\
\hline Tsupi2 & massive wall internal surface temperature & ${ }^{\circ} \mathrm{C}$ & in the massive wall internal surface at $120 \mathrm{~cm}$ from the floor & Hukseflux & $\pm 0.1^{\circ} \mathrm{C}$ \\
\hline Tsupi3 & massive wall internal surface temperature & ${ }^{\circ} \mathrm{C}$ & in the massive wall internal surface at $120 \mathrm{~cm}$ from the floor & Hukseflux & $\pm 0.1^{\circ} \mathrm{C}$ \\
\hline Tsupi4 & massive wall internal surface temperature & ${ }^{\circ} \mathrm{C}$ & in the massive wall internal surface at $120 \mathrm{~cm}$ from the floor & Hukseflux & $\pm 0.1^{\circ} \mathrm{C}$ \\
\hline Tsupi5 & massive wall internal surface temperature & ${ }^{\circ} \mathrm{C}$ & at half-height of the massive wall internal surface & TM1 Delta-T & $\pm 0.1^{\circ} \mathrm{C}$ \\
\hline HF1 & heat flux & $\mathrm{W} / \mathrm{m}^{2}$ & in the massive wall internal surface at $120 \mathrm{~cm}$ from the floor & Hukseflux & $\pm 50 \mu \mathrm{V} / \mathrm{W} / \mathrm{m}^{2}$ \\
\hline HF2 & heat flux & $\mathrm{W} / \mathrm{m}^{2}$ & in the massive wall internal surface at $120 \mathrm{~cm}$ from the floor & Hukseflux & $\pm 50 \mu \mathrm{V} / \mathrm{W} / \mathrm{m}^{2}$ \\
\hline HF3 & heat flux & $\mathrm{W} / \mathrm{m}^{2}$ & in the massive wall internal surface at $100 \mathrm{~cm}$ from the floor & FRM-100 WVNTRONIC & $\pm 1.5 \mathrm{~W} / \mathrm{m}^{2}$ \\
\hline
\end{tabular}




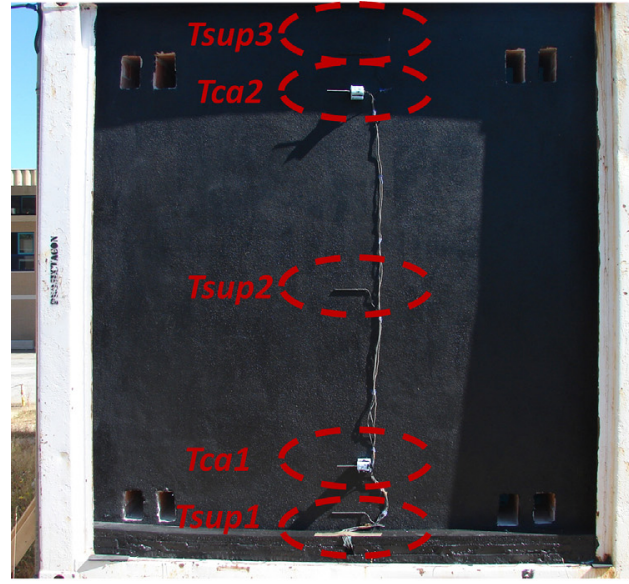

a)

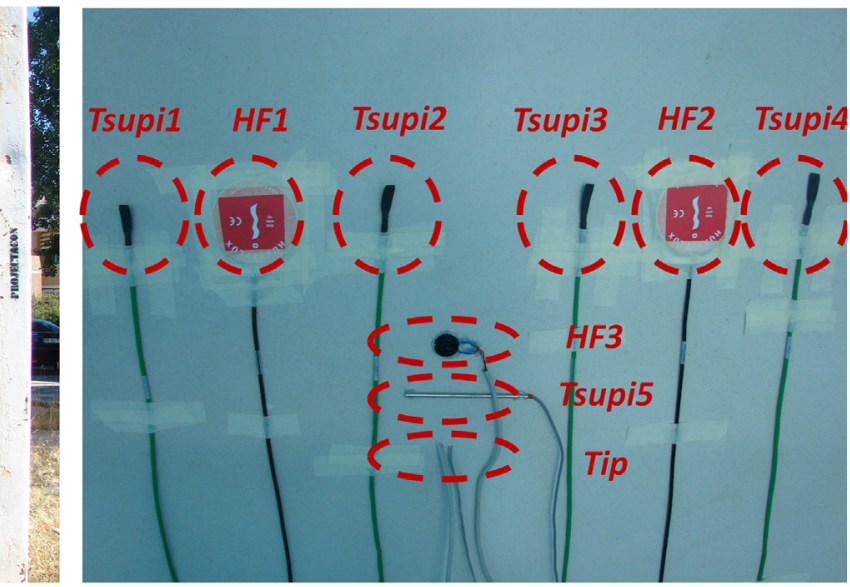

b)

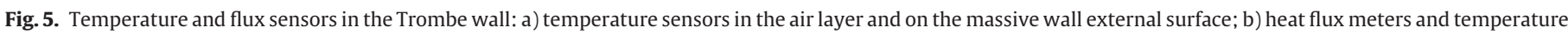
sensors placed on the massive wall internal surface.

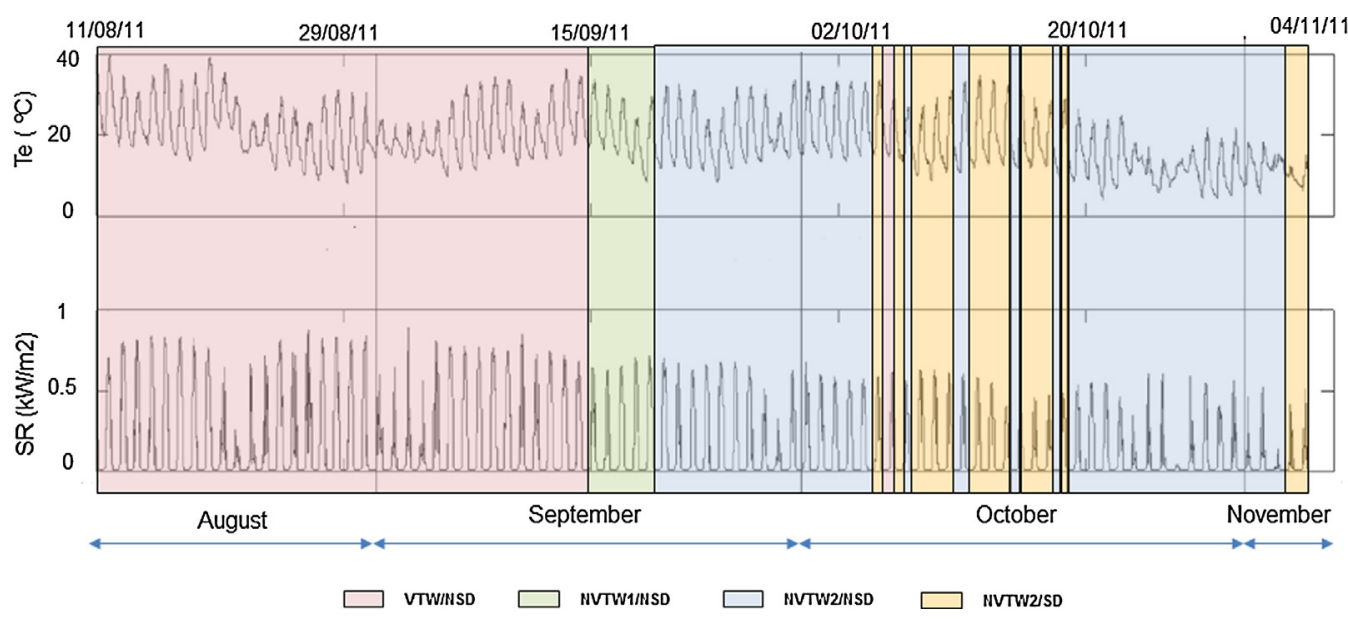

Fig. 6. Outdoor Conditions: total solar radiation intensity $(S R)$ and air temperature (Te).
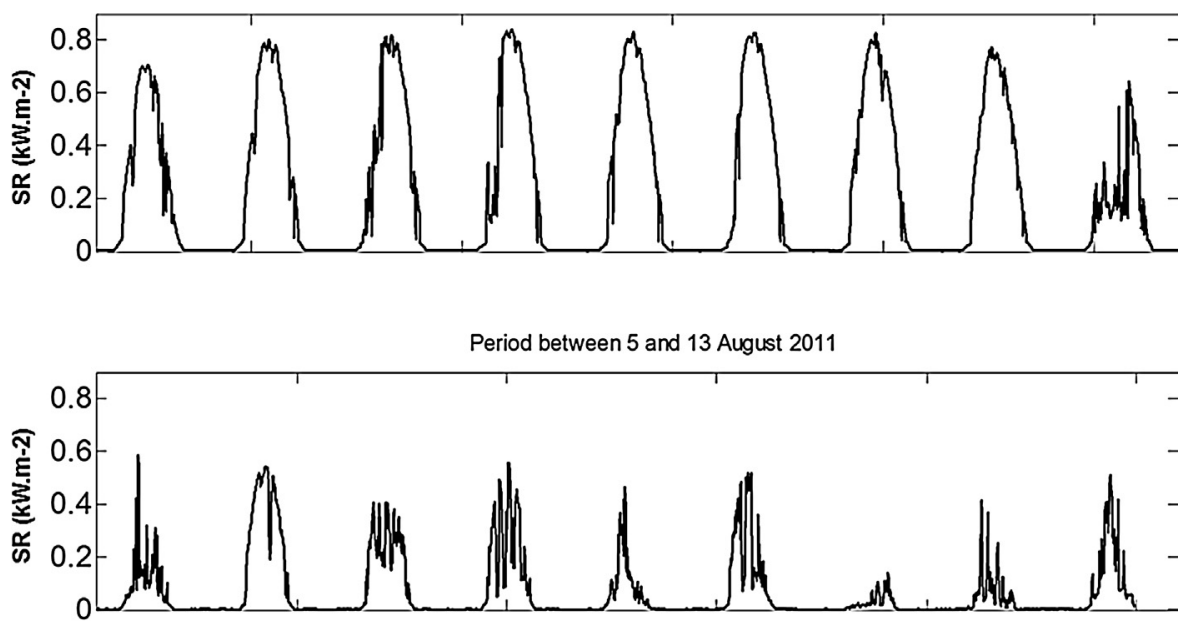

Period between 27 October and 4 November 2011

Fig. 7. Total solar radiation intensity (SR): period between 5 and 13 August 2011 and period between 27 October and 4 November 2011.

mum value around $4.00^{\circ} \mathrm{C}$ during the night periods of the last days of October. During August, the average outdoor temperature was $21.80^{\circ} \mathrm{C}$, reaching a maximum value of $39.73^{\circ} \mathrm{C}$ and a minimum of $8.97^{\circ} \mathrm{C}$. During September, those values were $20.18^{\circ} \mathrm{C}, 34.71^{\circ} \mathrm{C}$ and $8.25^{\circ} \mathrm{C}$, respectively, while in October reached $16.70^{\circ} \mathrm{C}, 34.71^{\circ} \mathrm{C}$ and $4.02{ }^{\circ} \mathrm{C}$, respectively. 
The values of $S R$ and Te showed above corroborate the fact that this region is characterized by high temperature ranges and has potential for the use of solar energy resources.

The influence of the solar radiation and the exterior temperature variation in the Trombe wall thermal behaviour can be identified in the temperature fluctuation obtained in the different points of the system, as it will be explained in the following sections.

\subsection{Air layer temperature variation}

The temperatures obtained in the air layer depend on the outside conditions, specifically on the solar radiation intensity. The values obtained showed the system ability to store heat in the air layer, as well as the influence of the ventilation openings and exterior shading devices. These conditions led to different temperature values at the bottom and at the top of the air layer.

As expected, the temperature values at the top of the air layer,Tca2, were always higher than those obtained at the bottom,Tca1. During some periods of the experimental work, the values of Tca2 exceed the values of Tca1 in more than $19^{\circ} \mathrm{C}$, as it can be seen in Fig. 8, in the 21st and 22nd October. In this period, the ventilation openings were closed with obturators Type 2 and the shading devices were not activated (NVTW2/NSD), increasing the greenhouse effect created in the air layer, which consequently led to rising temperatures and higher gradients between the bottom and the top. During August, the maximum values of Tca1 and $T c a 2$ were $54.48^{\circ} \mathrm{C}$ and $57.92^{\circ} \mathrm{C}$, respectively, corresponding to the hours characterized by higher values of solar radiation, and the minimum values were $15.10^{\circ} \mathrm{C}$ and $18.95^{\circ} \mathrm{C}$, registered during the night periods. During September and the beginning of October, those temperatures exceed $60^{\circ} \mathrm{C}$, as it can be observed in Fig. 8 . Once the temperature sensor does not record values above $60^{\circ} \mathrm{C}$, it was not possible to show, precisely, at this stage, how this limit was exceeded but the analysis of the curves development allowed to estimate that several times the temperature values were higher that $60^{\circ} \mathrm{C}$. The values obtained by the sensor Tca2 exceeded $60^{\circ} \mathrm{C}$ between the 14:50 and 16:30 on 13th September. During this period, there was ventilation on the massive wall and no shading devices were used (VTW/NSD). These values show that high temperature values can be achieved in the air layer during the day for periods with high values of $T e$ and $S R$, if there is heat transfer by air convection through the openings and if no shading devices are used. It is visible the overheating impact on the temperatures variation.

As referred previously, two types of obturators were used to close the air openings in order to evaluate the influence of the air convection.

When the obturators Type 1 were placed in the air openings (NVTW1/NSD), Tca2 values exceeded $60^{\circ} \mathrm{C}$ earlier comparing with the period described previously, around 12:15, and this value remained until 17:15. This situation was repeated between the 15th and the 19th September. This was due to the fact that the air flow through the openings was residual and therefore, the greenhouse effect in the air layer occurred earlier and during a longer period, increasing the indoor temperature. During this period, the minimum values of Tca1 and Tca2 were $16.86^{\circ} \mathrm{C}$ and $22.44^{\circ} \mathrm{C}$, respectively, and the shading devices were not placed outside. When the obturators Type 1 were replaced by the obturators Type 2 , the residual air flow through the openings was eliminated. It was also maintained the situation of no shading devices outside (NVTW2/NSD). In this case, the values of Tca2 exceeded $60^{\circ} \mathrm{C}$ between the 12:00 and 18:00, but the value of Tca1 also reached values higher than $60^{\circ} \mathrm{C}$ between the $13: 00$ and 15:00. These results showed that, when there was no ventilation in the massive wall, the values of Tca 1 and Tca2 were higher than $60^{\circ} \mathrm{C}$ for a longer period of time, comparing with the previous period. This situation occurred during the beginning of the afternoon, at 14:35 on 19th September and at 15:25 on 4th October and it can be observed in Fig. 8. In this case, the minimum values of Tca1 and Tca2 were $17.49^{\circ} \mathrm{C}$ and $21.46^{\circ} \mathrm{C}$, respectively. The obtained results for the period starting at 4 th October showed that the maximum temperature values increased due to the changes in the ventilation system and in the shading devices operation. The highest temperature values in the air layer corresponded to experimental periods with no shading devices placed outside, while the lowest values resulted, simultaneously, from the placement of the shading devices and closing the air openings (NVTW2/SD). For example, between 13:25 on 7th October and 16:40 on 10th October, Tca1 and Tca2 reached, respectively, the maximum values of $45.60^{\circ} \mathrm{C}$ and $51.92^{\circ} \mathrm{C}$ and the minimum values of $14.73^{\circ} \mathrm{C}$ and $16.86^{\circ} \mathrm{C}$. The average difference between the two temperatures was only $3.57^{\circ} \mathrm{C}$, reaching the value of $10^{\circ} \mathrm{C}$ during the day and around $1.27^{\circ} \mathrm{C}$ during the night. During the period mentioned above, between 18:15 on 7th October and 12:55 on 9th October, the temperature values on the massive wall internal surface, Tsupi5, were higher than the temperature values obtained at the bottom of the massive wall,Tca1, which was due to the system heat storage capacity during the previous period, characterized by the closure of the air openings and the non-placement of shading devices. The difference between these two temperatures decreased gradually due to the heat flow between the massive wall and the air layer until 13:00, when a flow inversion occurred. So, Tca1 value became higher than the temperature value at the massive wall internal surface until 18:35. From this time, the heat flux inversion occurred once again and Tca1 values started to decrease and take lower values than the ones obtained in the internal surface, until 12:00 on 10th October. These results characterized the heat transfer during the day and the night periods in the Trombe wall system with the ventilation system closed and with the shading devices activated (NVTW2/SD). The use of the shading devices during the night reduced the heat transfer between the air layer and the external environment when the massive wall internal surface temperature was higher than the air layer temperature and the heat flux occurred from the internal to the external environment, Fig. 9.

\subsection{Massive wall temperature variation}

In this section, the temperatures values across the massive wall, Tsup2, Tsupi5 and Tip, represented in Fig. 4, are analysed. The relation between those values reflects, in addition to the influence of the parameters defined so far, the ventilation openings and the shading device effect, the massive wall storage capacity and the heat delay through the Trombe wall. The temperature values obtained across the massive wall had an oscillation pattern similar to the ones obtained in the air layer. However, the massive wall external surface temperatures reached higher values than the ones obtained in the air layer. This is due to the high absorption capacity of the external surface, which was painted black. In this case, the values exceeded $60^{\circ} \mathrm{C}$ during a large period of the experimental work. The analysis of Fig. 10 also leads to the conclusion that the external surface temperature values were considerably higher than the ones obtained at the middle and on the internal surface of the massive wall. The temperature at $17 \mathrm{~cm}$ of the thickness, reached the maximum value of approximately $42^{\circ} \mathrm{C}$ and the minimum of $13^{\circ} \mathrm{C}$. The maximum value occurred on 3rd October between 20:35 and 21:40, which corresponds to the experimental period with the placement of the obturators Type 1 and without shading devices (NVW1/NSD). The minimum value corresponded to the end of the experimental period. The outdoor air temperature and the solar radiation decreased substantially, which explains the low values obtained. The temperature values on the internal surface were slightly lower than the values in the middle of the massive 


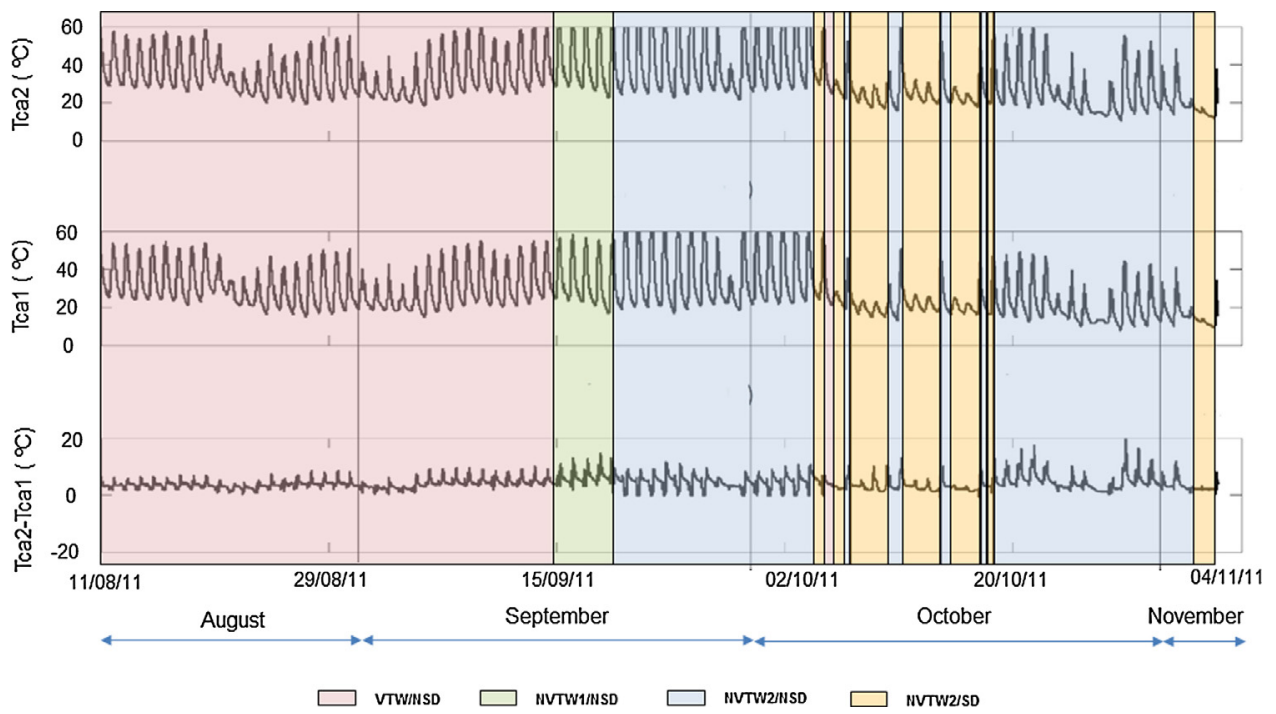

Fig. 8. Air layer temperature variation: Tca2- temperature at the top; Tca1-temperature at the bottom; Tca2-Tca1-difference between Tca2 and Tca1.

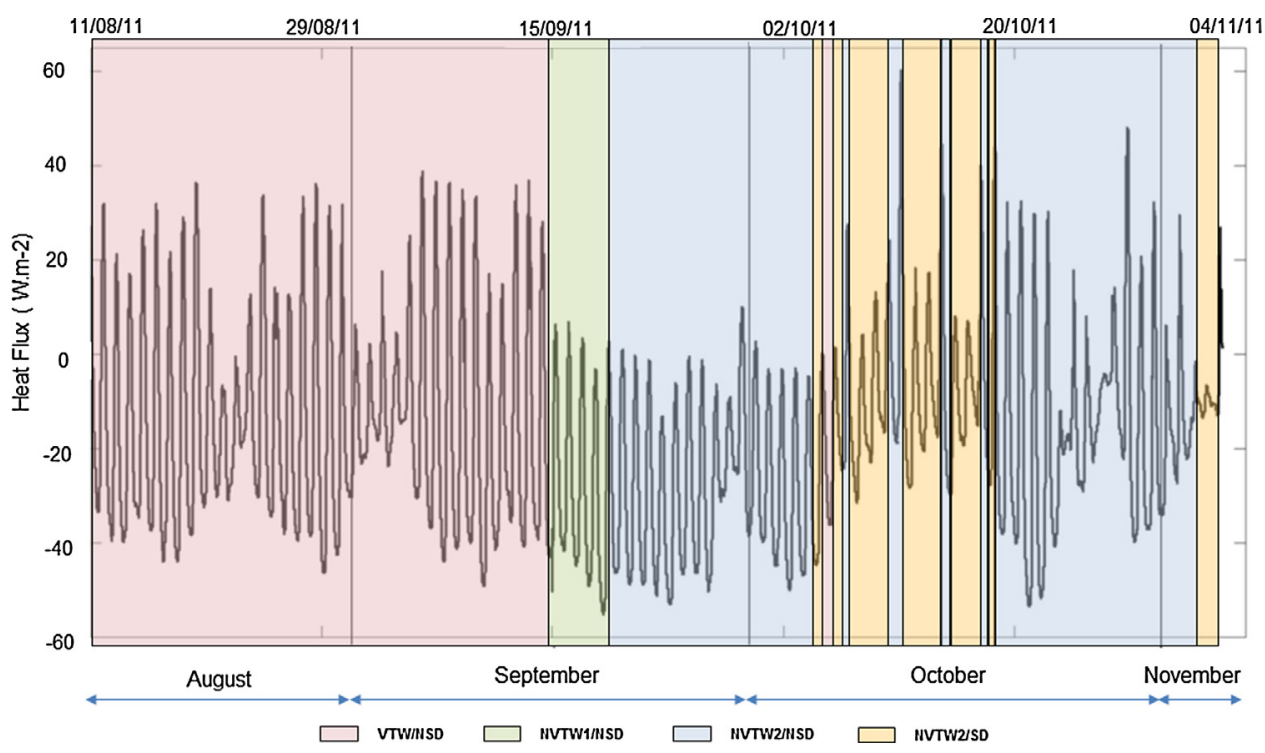

Fig. 9. Heat flux through the Trombe wall.

wall, with maximum and minimum values of $38.54{ }^{\circ} \mathrm{C}$ and $11.85^{\circ} \mathrm{C}$, respectively.

The differential between the values of Tsup2, Tip and Tsupi5 were also analysed and the results are presented in Fig. 11. The maximum differential value between the temperatures Tsup2 and Tip was $42.54{ }^{\circ} \mathrm{C}$ and the minimum was $8.42^{\circ} \mathrm{C}$, corresponding the last one to the period when the temperature inside the wall was higher than the one in the internal surface. The maximum differential between Tsup 2 and Tsupi 5 was $40.55^{\circ} \mathrm{C}$ and the minimum was $-0.60^{\circ} \mathrm{C}$. It was also observed that the difference between Tip and Tsupi5 showed significantly lower values when compared with the differential between Tsup2 and Tip, reaching a maximum of $11.03^{\circ} \mathrm{C}$ and a minimum of $-3.70^{\circ} \mathrm{C}$. The negative values mean that the heat flux direction was inverted during the night, taking place from the inside to the outside of the test cell. This was due to the fact that the test cell indoor temperature was higher than the air layer temperature. These results enable to conclude that the temperature variation across the massive wall is not proportional to its thickness and that there is a significant decrease in the transition from the outside to the inside of the wall. This is due to the increasing of the absorption coefficient resultant from the fact that the external surface is dark in colour, in addition to the greenhouse effect created in the air layer. Comparing the differential values between the middle and the internal surface of the massive wall, it can be concluded that the decrease is much lower and the values obtained are conditioned by the massive wall thermal properties, particularly the solid brick thermal mass and storage capacity. It should be noticed that the values obtained for the temperatures, especially in the superficial layers, are also influenced by the air convection phenomenon in the case of the ventilated Trombe wall.

The massive wall temperature variation was also analysed based on thermograms using a thermographic camera. The thermogram of the internal surface temperature stratification was obtained at 18:12 of 13 th September, Fig. 12, when there were no shading devices outside and no obturators in the air openings. The colour pattern shows that the internal surface temperatures were very high, achieving the minimum value of $36^{\circ} \mathrm{C}$ and the maximum of $48^{\circ} \mathrm{C}$. The thermographic analysis corroborates the results of the temperatures values obtained using the temperature sensors placed in the wall surface, showing that the temperatures at the 


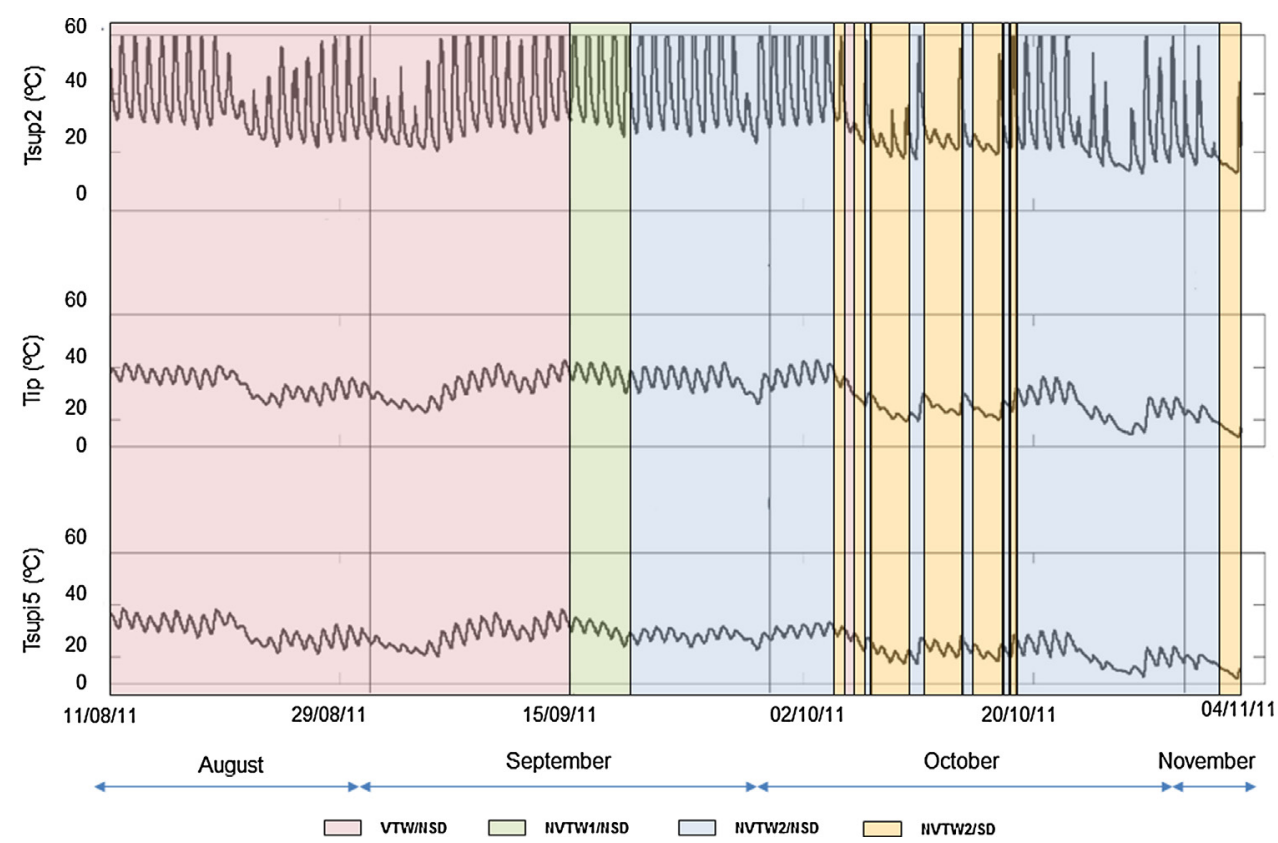

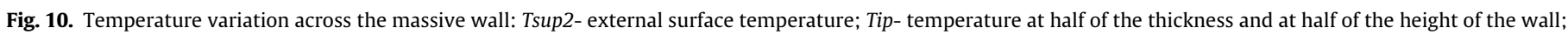
Tsupi5-internal surface temperature.

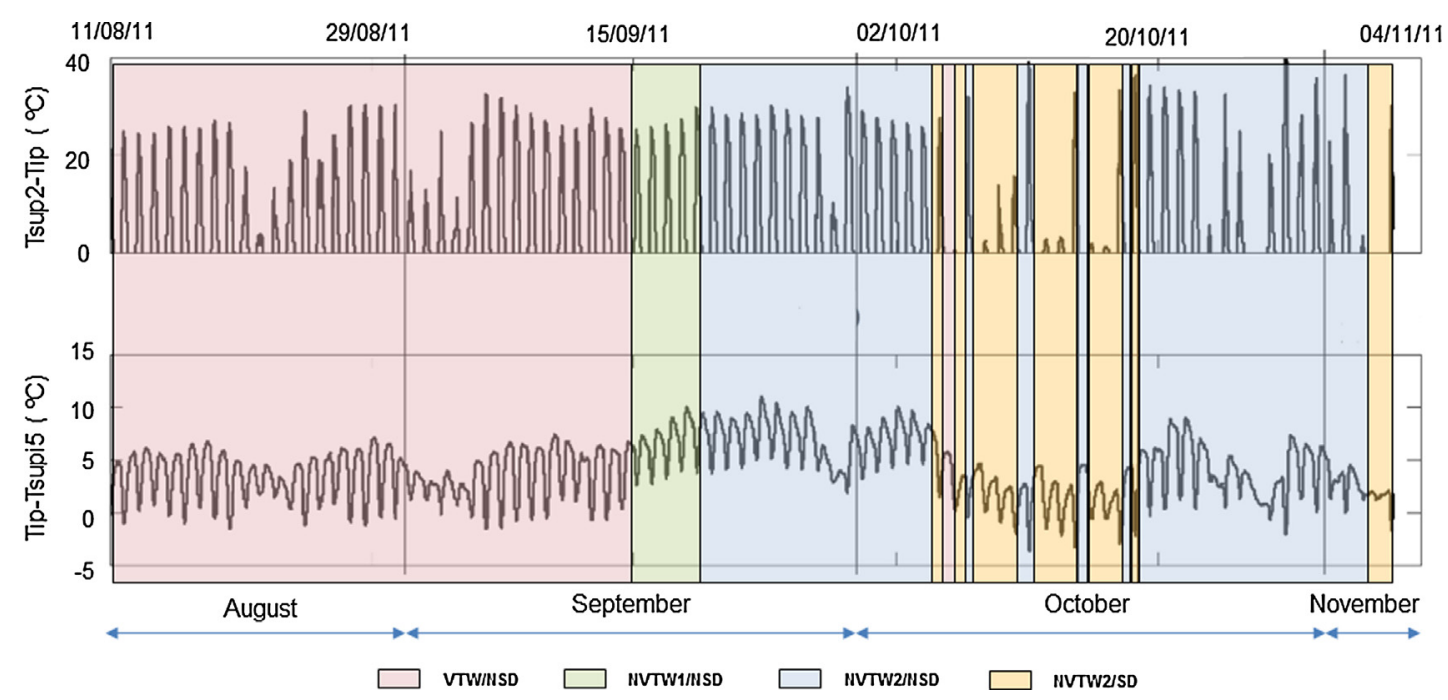

Fig. 11. Temperature variation across the massive wall: differential Tsup2-Tip and differential Tip-Tsupi5.

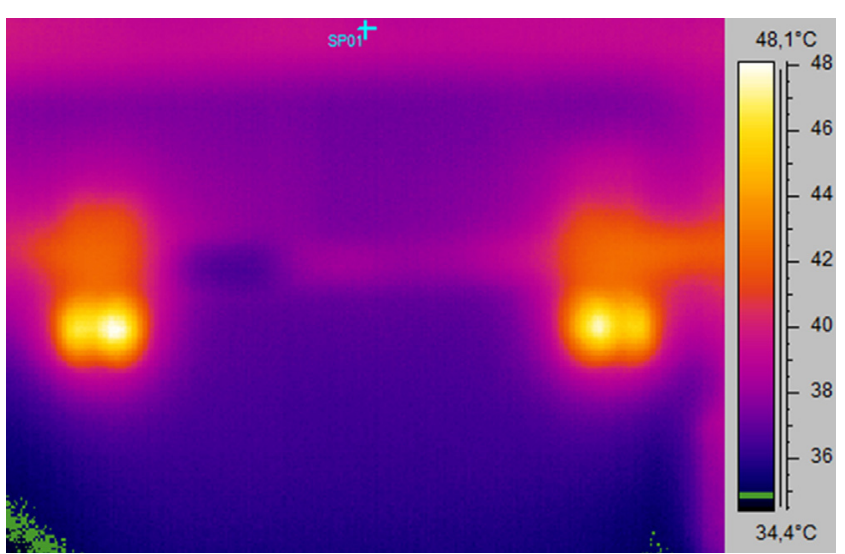

Fig. 12. Thermogram of the Trombe wall internal surface. top of the wall and near the air openings are much higher than the ones obtained at half-height of the wall.

\subsection{Indoor climate}

The analysis of the indoor test cell temperature is crucial to understand the Trombe wall contribution. In Fig. 13, the oscillation curves of the interior and exterior temperature and the differential between them are presented. The results obtained show that, in a large part of the test period, the temperature inside the test cell reached higher values than outside, causing the negative signal (the heat flux occurs from the inside to the outside) of the heat flux in most part of the period, as it can be seen in Fig. 9. However, an inversion in the signal temperature was observed in some periods of the experimental work and Te values became higher than Ti. This difference was influenced by the Trombe wall thermal performance conditioned by the ventilation system operation and the use of shading devices outside. A detailed analysis of the obtained 


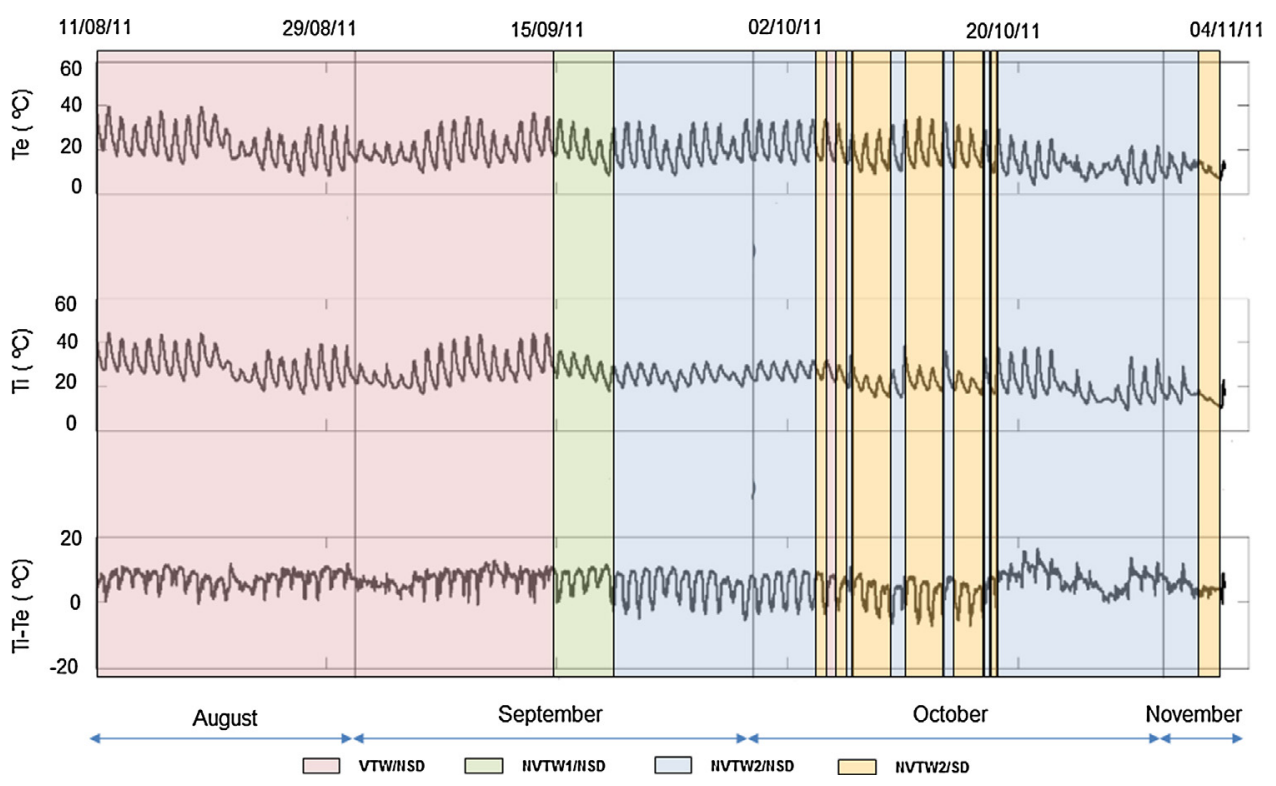

Fig. 13. Outdoor temperature $T e$, indoor temperature $T i$ and differential between $T i$ and $T e$.

values shows that the value of Ti varied between $9.38^{\circ} \mathrm{C}$ and $44.08^{\circ}$ $\mathrm{C}$, while the value of $\mathrm{Te}$ range between $4.02^{\circ} \mathrm{C}$ and $39.73^{\circ} \mathrm{C}$. This fluctuation decisively influence the heat flux through the system (Fig. 9). The temperature values obtained for the period between the 17:00 on 11th August and the $21: 10$ on 15th September is an example of this situation, Fig. 13. Ti was always higher than Te because the air openings in the massive wall were open(VTW/NSD). The values exceeded $\mathrm{Te}$ in $12.79^{\circ} \mathrm{C}$ and the average difference between the two temperatures reached the value of $7.29^{\circ} \mathrm{C}$. The maximum temperature differential between $T i$ and $T e$ is approximately $8{ }^{\circ} \mathrm{C}$ in the period between $14: 00$ and 07:00. In the period between 9:45 and 11:15 on 12th August, the difference between those temperatures was almost zero or less than $1^{\circ} \mathrm{C}$. The highest values of the differential occurred during the afternoon, between $13: 00$ and $16: 00$, or during the night and early morning, when the difference between $T i$ and $T e$ was around $11^{\circ} \mathrm{C}$.

During the placement of the obturators Type 1, Ti values were higher than $T e$, achieving an average value of about $7^{\circ} \mathrm{C}$. This was due to the fact that the air openings were not totally obstructed and allowed the heat transfer by air convection through them (NVTW1/NSD). When the obturators Type 2 were placed (NVTW2/NSD), the heat transfer by air convection was barred, leading to the temperatures sign inversion, which means that Te had higher values than $\mathrm{Ti}$ (Fig. 13). At this time, the difference between the two temperatures assumed an average value of $4.96^{\circ} \mathrm{C}$, and the outside temperature exceed the temperature inside the test cell in a maximum of $5.38^{\circ} \mathrm{C}$. During these periods, the heat flux values were much lower, Fig. 9. The placement of the outside shading devices influenced the temperature values obtained inside the test cell and, consequently, the differential between $T e$ and $T i$ and the heat flux values. Since 4 th October at 16.30 , the placement of the shading devices was combined with the opening or closing of the ventilation openings. For example, in the period between 13:25 on 7th October and 16:40 on 10th of the same month, the air openings remained closed and the thermal insulation boards were placed outside (NVTW2/SD). On the first day, Ti reached higher values than $T e$ but the difference between them decreased until the next day at 12:00 and Ti became higher than Te until the late afternoon. From this point, $T i$ was again higher than $T e$, but the differential value decreased until the 10:00 am of the next day, when Te started to increase until the end of the afternoon. In the periods when $T i$ was higher than $T e$, the difference between them reached $10^{\circ} \mathrm{C}$, which occurred during the night. This leads to the conclusion that the placement of the shading devices outside and the closure of the openings avoided the heat flux from the inside to the outside environment. The external temperature presented higher values than $\mathrm{Ti}$, reaching the differential of $6.45^{\circ} \mathrm{C}$, which corresponded to the time of the day when the external shading devices reduced the heat transfer by conduction, convection and radiation through the Trombe wall. In the period between 18th October and 2 th November, $T i$ values were again much higher than $T e$ values. In this period, the air openings remained closed and the external shading devices were not placed. The values of the temperature in the test cell exceeded the values of $T e$ in $16^{\circ} \mathrm{C}$ but when the values of $T e$ were higher than $T i$, the differential only reached the maximum value of $1.42^{\circ} \mathrm{C}$. When the ventilation openings were closed and the shading devices were not activated, the temperature inside the test cell exceeded the value of the external temperature in $9^{\circ} \mathrm{C}$, which demonstrates the ability of the system to store heat during the day and release it during the night.

Although, as expected, placing the shading devices during the night and letting the air openings closed reduced the heat transfer from the inside to the outside of the test cell (NVTW2/SD) and consequently the fluctuation of temperatures through the wall.

In addition to the detailed analysis presented above, temperature diagrams across the Trombe wall, Fig. 14, allow to highlight the Trombe wall thermal behaviour under different conditions of ventilation system and shading device operation. The temperature fluctuation is represented for the different configurations, for different days of the measurement period, but for the same hours of the day. Although these diagrams represent temperatures variation, it is necessary to consider the solar radiation intensity values obtained for those days in the results analysis given that, as already referred, this variable has a decisive role in the temperature values. $S R$ values decreased from the 19th August to the 3rd November.

Analysing the temperatures fluctuation during the day, it can be observed that the highest fluctuations values occurred at 14:00, corresponding to the time of the day with higher $S R$ values. It is also verified that the VTW/NSD configuration for 19th August, the NVTW/NSD for 17th September and the NVTW/NSD for 2nd 

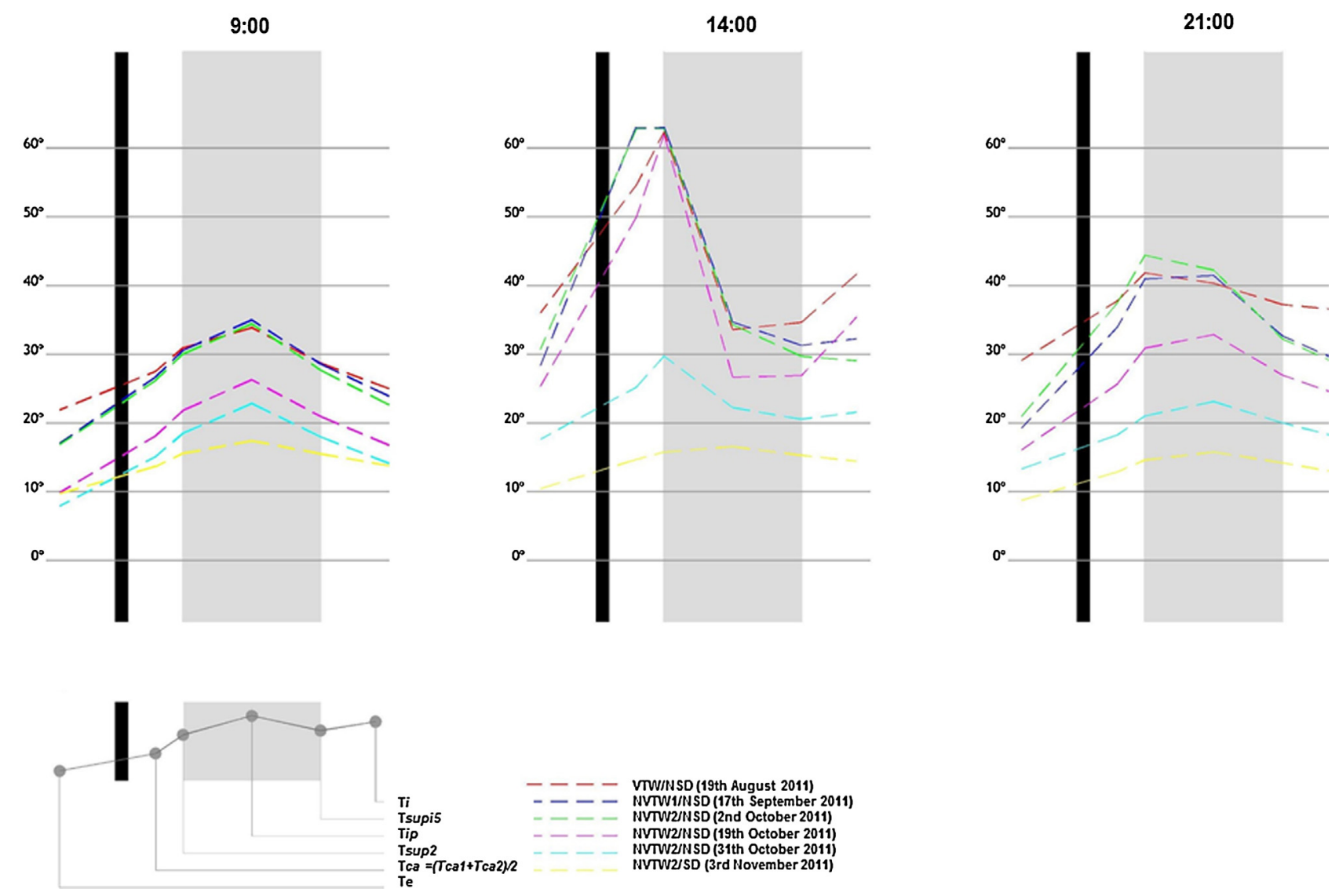

Fig. 14. Temperatures Diagrams.

October had temperature curves with similar development pattern at 9:00. However, at 14:00, the influence of the greenhouse effect created in the air layer by the closure of the air openings led to higher values of Tsup2 in the case of the NVTW, when compared with the VTW.

Comparatively, in the remaining hours, temperature fluctuations in the various point of the wall were less significant.

It is also noticeable that, for days with higher $R S$ values, temperature fluctuations were higher due to the heat storage that occurred in the air layer and also to the heat delay. Furthermore, the fact that there is no shading device activated during the days of cooling season periods (August and September) led to high temperatures values in the different points of the Trombe wall layers and in the interior of the test cell. At 21:00, the values of Ti achieved values near $30^{\circ} \mathrm{C}$ and $40^{\circ} \mathrm{C}$, showing the overheating effect that occurred during the periods of high $S R$ values.

Considering the situation of NVTW2/NSD for 31st October, Ti values were near $20^{\circ} \mathrm{C}$. This reveals that a temperature comfort can be achieved during the night periods if the ventilation system is open during the periods of higher $S R$ values and if the shading device is activated at the late afternoon.

In the case of the NVTW2/SD, and for days with lower SR values, the temperatures fluctuation for the different hours of the day was very small, showing the heat flow reduction through the system.

It is also observed the high differential between the temperature values of Tsup2 and Tip at 14.00, which decreased at 21:00. In addition, an increase in Tip values is also verified at this moment. This situation shows, once again, the existence of the heat delay in the system. The heat was released gradually and led to $T i$ values at 21:00 that were not much lower than those obtained at 14:00. The fact that Tsupi5 presented higher values than Ti during the night period also showed that the heat release occurred gradually during the day.

\section{Conclusions}

The analysis of the obtained values for the different variables measured during the experimental work give an important contribution to the knowledge of the Trombe wall thermal performance submitted to the real weather conditions of a Portuguese region with high temperatures range. The ventilation openings and the external shading devices operation effects were analysed. The study leads to the conclusion that these elements have a decisive role in the Trombe wall behaviour. It also allowed to fill some gaps in what concerns to the temperature stratification in the air layer and across the massive wall. The experimental results showed that the temperatures in the air layer and along the massive wall presented a similar oscillation pattern, exceeding $60^{\circ} \mathrm{C}$. The temperature values at the top of the air layer were always higher than those obtained at the base. During some periods, the values at the top exceeded the values at the bottom in more than $19^{\circ} \mathrm{C}$, when the ventilation openings were closed and the shading devices were not activated. This situation increased the greenhouse effect created in the air layer and consequently led to rising temperatures and to higher gradients between the bottom and the top. So, the highest temperatures values were obtained when the ventilation system was closed and when the external protection devices were not activated. In this case, it was also observed that higher values were obtained during a longer period when compared with the periods when there was additional heat transfer by air convection through the openings. The temperatures variation across the massive wall was not proportional to its thickness and there was a significant decrease from 
the outside to the inside of the wall due to its heat storage capacity. The temperature in the middle of the wall varied between $42^{\circ} \mathrm{C}$ and $13^{\circ} \mathrm{C}$. When the ventilation system was closed and the protection devices were not activated, the temperature inside the test cell exceeded the outside temperature value in $9{ }^{\circ} \mathrm{C}$, which demonstrates the system ability to store and release heat. Although, as expected, it was observed that not placing the shading devices during the night and letting the air openings closed reduced the heat transfer from the inside to the outside of the test cell. The temperature comfort of $20^{\circ} \mathrm{C}$ was achieved inside the test cell, which corresponds to the value defined in the Portuguese regulation for the heating season. Although the operation of the air openings and the placement of the shading devices were aleatory, it was possible to identify their influence on the temperatures values measured in different points of the wall and inside the test cell. It was also possible to establish a link between the results obtained for the various variables considered, which will allow, in future work, to adjust and optimize the performance of this passive solar system for different conditions.

\section{Acknowledgment}

This work was partially supported by the FCT (Portuguese Foundation for Science and Technology) through the project PEstOE/ECI/UI4082/2013 (C-MADE).

\section{References}

[1] A. Fernández-González, Analysis of the thermal performance and comfort conditions produced by five different passive solar heating strategies in the United States midwest, Sol. Energy 81 (2007) 581-593.

[2] P. Raman, S. Mande, V. Kishore, A passive solar system for thermal comfort conditioning of buildings in composite climates, Sol. Energy 70 (4) (2001) 319-329.

[3] P. Mendonça, Habitar sob uma Segunda Pele: Estratégias para a Redução do Impacto Ambiental de Construções Solares Passivas em Climas Temperados, Doctorate Thesis in Civil Engineering, University of Minho, Portugal, 2005. [Consulted in November 2012]. Available in: http://repositorium.sdum. uminho.pt/bitstream/1822/4250/9/TeseDoutMendonca9.pdf.

[4] H. Gonçalves, J. Graça, Conceitos Bioclimáticos para os Edifícios em Portugal, INETI, Lisboa, 2004. [Consultado em Maio 2009]. Disponível em: http:// repositorio.lneg.pt/handle/10400.9/1323.

[5] S.A.M. Burek, A. Habeb, Air flow and thermal efficiency characteristics in solar chimneys and Trombe walls, Energy Build. 39 (2007) 128-135.

[6] T. Özbalta, S. Kartal, Heat gain through Trombe wall using solar energy in a cold region of Turkey, Sci. Res. Essays 5 (2010) 2768-2778.

[7] N.P. Nwachukwu, W.I. Okonkwo, Effect of an absorptive coating on solar energy storage in a Trombe wall system, Energy Build. 40 (2007) 371-374.

[8] K. Hamia, B. Draouib, O. Hamib, The thermal performances of a solar wall, Energy 39 (2012) 11-16.

[9] Á. Ruiz, J. Salmerón, R. González, S. Álvarez, A calculation model for Trombe walls and its use as a passive cooling, Proceedings of International Conference Passive and Low Energy Cooling for the Built Environment, 2005, Santorini, Greece, pp 365-369.

[10] G. Gan, A parametric study of Trombe wall for passive cooling of buildings, Energy Build. 27 (1998) 37-43.

[11] J. Jie, Y. Hua, P. Gang, J. Bin, H. Wei, Study of PV- Trombe wall assisted with DC fan, Build. Environ. 42 (2008) 3529-3539.

[12] J. Khedari, N. Rachapradit, J. Hirunlabh, Field study of performance of solar chimney with air-conditioned building, Energy 28 (2003) 1099-1114.

[13] X. Fang, Y. Li, Numerical simulation and sensitivity analysis of lattice passive solar heating walls, Build. Environ. 69 (2000) 55-66.

[14] W. Chen, W. Liu, Numerical analysis of heat transfer in a passive solar composite wall with porous absorber, Appl. Therm. Eng. 28 (2008) 1251-1258

[15] B. Jianga, J. Jib, H. Yib, The influence of PV coverage ratio on thermal and electrical performance of photovoltaic-Trombe wall, Renew. Energy 33 (2008) 2491-2498.

[16] J. Lie, L. ChengLong, S. Wei, Y. HangCheng, H. Wei, G. Pei, An improved approach for the application of Trombe wall system to building construction with selective thermo-insulation façades, Chin. Sci. Bull. 54 (2009) 1949-1956.
[17] J. Shen, S. Lassue, L. Zalewski, L. Huang, Numerical study on thermal behavior of classical or composite Trombe solar walls, Energy Build. 39 (2007) 962-974

[18] A. Mezrhab, M. Rabhi, Modeling of the thermal transfers in an enclosure of the Trombe wall type, Int. Sci. J. Altern. Energy Ecol. 6 (2008) 9-14.

[19] A. Martins, Contribuição da parede de Trombe na redução do consumo energético dos edifícios. Master Dissertation in Civil Engineering, University of Trás-os-Montes and Alto Douro, Vila Real, Portugal, 2010.

[20] F. Stazi, C. Di Perna, C. Filiaci, A. Stazi, The solar wall in the Italian climates, world academy of science, Eng. Technol. 37 (2008) 31-39.

[21] H. Chan, S.B. Riffat, J. Zhu, Review of passive solar heating and cooling technologies, Renew. Sustain. Energy Rev. 14 (2009) 781-789.

[22] D. Constantinescu, Theoretical and Experimental Analysis of Two Passive Solar Heating Systems, National Building Research Institute -INCERC, Bucharest, Romania ConstructII, No. 1, 2007.

[23] A. Briga-Sá, Parede de Trombe: Análise Experimental e Simulação de Desempenho Térmico, PhD Thesis in Civil Engineering, University of Beira Interior, 2011.

[24] A. Briga-Sá, A. Paiva, J. Boaventura-Cunha, J.C. Lanzinha, Contribution of the Trombe wall to sustainable buildings: experimental work, 38th IAHS World Congress on Housing Science - Istanbul, Turkey, 16-18 April, 2012.

[25] B. Chen, J., Zhao, C., Chen, Z. Zhuang, Experimental Investigation of Natural Convection in Trombe Wall Systems, Proceedings of the Sixth International Conference for Enhanced Building Operations, Shenzhen, China, November 6-9, 2006, Envelope Technologies for Building Energy Efficiency Vol.II-3-1.

[26] W. Liping, L. Angui, A numerical Study of Trombe Wall for Enhancing Stack Ventilation in Buildings. Proceedings of PLEA2006 - The 23rd Conference on Passive and Low Energy Architecture, Geneva, Switzerland, 6-8 September 2006.

[27] D.T. Chen, S.K. Chaturvedi, T.O. Mohieldin, An approximate method for calculating laminar natural convective motion in a trombe-wall channel, Energy 19 (1994) 259-268.

[28] J. Lie, L. ChengLong, S. Wei, Y. HangCheng, H. Wei, G. Pei, An improved approach for the application of Trombe wall system to building construction with selective thermo-insulation façades, Chin. Sci. Bull. 54 (2009) 1949-1956.

[29] J. Shen, S. Lassue, L. Zalewski, L. Huang, Numerical study on thermal behavior of classical or composite Trombe solar walls, Energy Build. 39 (2007) 962-974.

[30] Y. Liu, D. Wang, C. Ma, J. Liu, Numerical and experimental analysis of the air vent management and heat storage characteristics of a Trombe wall, Sol. Energy 91 (2013) 1-10.

[31] Y.A. Kara, A.K. Çırakman, C. Arslantürk, Solar Energy Storage in Building Structure for Solar Space Heating. International Conference and Exhibition on Green Energy \& Sustainability for Arid Regions \& Mediterranean Countries, 2009.

[32] M. Telkes, Trombe Wall With Phase Change Storage Material. Proceedings of the 2nd National passive solar conference, USA, 1978.

[33] W. Sun, J. Ji, C. Luo, W. He, Performance of PV-Trombe wall in winter correlated with south façade design, Appl. Energy 88 (2011) 224-231.

[34] B. Chen, X. Chen, Y. Ding, X. Jia, Shading effects on the winter thermal performance of the Trombe wall air gap: An experimental study in Dalian, Renew. Energy 31 (2006) 1961-1971.

[35] F. Stazi, A. Mastrucci, C. di Perna, Trombe wall management in summer conditions: an experimental study, Sol. Energy 86 (2012) 2839-2851.

[36] ISO 13790:2008 (E) (2008), Energy Performance of Buildings-Calculation of Energy Use for Space Heating and Cooling. 2008.

[37] A. Briga-Sá, A. Martins, J. Boaventura-Cunha, J. Carlos Lanzinha, A. Paiva Energy performance of Trombe walls: adaptation of ISO 13790:2008(E) to the Portuguese reality, Energy Build. 74 (2014) 111-119.

[38] B. Chen, H. Chen, S. Meng, X. Chen, P. Sun, Y. Ding, The effect of Trombe wall on indoor humid climate in Dalian, China, Renew, Energy 31 (2006) 333-343.

[39] A. Martins, A. Briga-Sá, A. Paiva, Characteristics of the Trombe Wall and its Application in Portugal, 37th IAHS World Congress on Housing Science, 26-29 October, Universidad de Cantabria, Santander, Spain, 2010.

[40] H. Gonçalves, M. Oliveira, A. Patricio, P. Cabrito, Passive solar buildings in Portugal, experiences in the last 20 years, INETI, Lisbon, Portugal, 2007.

[41] Decreto-lei n. ${ }^{\circ} 80 / 06$, Regulamento das Características do Comportamento Térmico dos Edifícios - RCCTE (Portuguese thermal regulation for buildings), 4 April 2006

[42] P.H. Baker, H. Dijk, PASLINK and dynamic outdoor testing of building components, Build. Environ. 43 (2008) 143-151.

[43] A.A. Hassanain, E.M. Hokam, T.K. Mallick, Effect of solar storage wall on the passive solar heating constructions, Energy Build. 43 (2010) 737-747.

[44] A. Wilson, Thermal Storage Wall Design Manual, New Mexico Solar Energy Association in Santa Fee, 1979.

[45] F. Moita, Energia Solar Passiva, Argumentum 2ํㅡㄹ dição, Direcção Geral de Energia e Geologia, 2010 